\title{
EVALUATION OF THE ROLE OF HEPCIDIN IN PREDICTING THE THERAPEUTIC EFFICACY OF ERYTHROPOIESIS-STIMULATING AGENT TREATMENT IN PATIENTS OF CHRONIC RENAL FAILURE
}

\author{
Hoda El-HadyAhmed ${ }^{(1)}$, Amal Emam El-Maghraby ${ }^{(2)}$ \\ Departments of Clinical Pathology ${ }^{(1)}$, General Medicine ${ }^{(2)}$,Benha Teaching Hospital; \\ Benha, Egypt
}

$\begin{array}{ll}\text { Corresponding Author: } & \text { ABSTRACT } \\ \text { Hoda El-Hady Ahmed, } & \text { Background: Chronic kidney disease is associated with increase serum } \\ & \text { hepcidin level which contributes to severity of anemia and to resistance of } \\ \text { E-mail: huda.elhady@yahoo.com, } & \text { erythropoiesis stimulating agents and dysregulation of iron hemostasis. } \\ \text { tel: } 01140026110 & \text { Serum hepcidin correlates positively with ferritin in patients on } \\ & \text { hemodialysis. Subjects and Methods: fifty patients of end stage renal } \\ & \text { disease(ESRD) on regular hemodialysis and on erythropoietin therapy, } \\ & \text { twenty seven males, twenty three females and twenty subjects as control. } \\ & \text { Group matched for age, gender were clinically assessed and laboratory } \\ & \text { investigations were done in the form of serum urea, creatinine, iron profile } \\ & \text { (serum iron, ferritin, total iron binding capacity), serum erythropoietin, } \\ & \text { serum hepcidin, and hemoglobin. Results: There is significant negative } \\ & \text { correlation between hepcidin and hemoglobin, iron, total iron binding } \\ \text { capacity and erythropoietin (P<0.01) and positive significant correlation } \\ \text { between serum hepcidin and serum ferritin (P<0.05) in both male and } \\ \text { female groups. Hepcidin and serum ferritin are higher in patients groups } \\ \text { than control but erythropoietin is lower in patients groups than control with } \\ \text { statistical significance (P<0.01). } \\ \text { Key words: Hepcidin, erythropoietin, chronic renal failure. }\end{array}$

\section{INTRODUCTION}

A nemia of chronic renal disease is a multifactorial problem. Inflammation and impaired renal clearance increase plasma hepcidin, inhibiting duodenal iron absorption and sequestration iron in macrophages, this can cause iron deficiency, resistance to endogenous, exogenous erythropoietin. ${ }^{[1]}$

Hepcidin is a small defensin-like peptide produced primarily by hepatocytes and macrophages. It is considered the main regulator of iron metabolism. Through controlling dietary iron absorbed inthe duodenum and the iron release by reticuloendothelial cells. It is upregulated by different stimuli such as iron overload and inflammation and downregulated by anemia, iron deficiency and hypoxia. ${ }^{[2]}$

Chronic kidney disease (CKD) is associated with increase serum hepcidin levels, which contributes to the severity of anemia and to resistance of erythropoiesis stimulating agents and dysregulation of iron hemostasis. ${ }^{[3]}$
Ferritin is a significant predictor of hepcidin levels in absence of apparent inflammation. Serum hepcidin levels correlated positively with ferritin in patients on hemodialysis and is considered a marker of inflammation as highly sensitive -CRP. ${ }^{[4]}$

Recombinant human erythropoietin has been used in chronic renal failure patients suffering from chronic anemia and although it improves outcome of patients on regular chronic dialysis but few numbers of patients have recorded failure of response to epoetin therapy. Many factors are contributed to resistance such as iron deficiency either functional or absolute, infection and inflammation disrupt iron metabolism and increase release of pro-inflammatory cytokines that inhibit erythropoiesis. ${ }^{[5]}$

Our study aims to evaluate the role of serum hepcidin in predicting the therapeutic efficacy of erythropoiesis-stimulating agent treatment in patients with chronic renal failure. 


\section{SUBJECTS AND METHODS}

This study was carried out in Benha Teaching Hospital Clinical Pathology and Internal Medicine Departments.

The study included a total number of seventy subjects, twenty healthy persons and fifty patients. The patients groups are classified according to gender into males group (group I) and females group (group II) as reference range of iron, ferritin and TIBC are different between males and females. The patients are presenting to the Benha teaching hospital for renal dialysis. Their diagnosis was confirmed by medical history, clinical examination , laboratory investigations and radiological examination.

These subjects were classified into:

\section{Group I}

Twenty seven males patients with renal failure, their age ranged from 29 to 67 years with $($ mean \pm SD) of $(50.2 \pm 10.2)$. They suffer from chronic renal failure and are subjecting to regular hemodialysis 3 times per week .

\section{Group II}

Twenty three females patients with renal failure, their age ranged between 32 and 60 years with (mean \pm SD) of $(48.8 \pm 8.4)$. They suffer from chronic renal failure and are subjecting to regular hemodialysis 3 times per week .

\section{Group III (Control group)}

Twenty healthy subjects, 10 males and 10 females their age ranged between 27 and 57 years with (mean $\pm \mathrm{SD}$ ) of $(45.1 \pm 8.9)$, were chosen from healthy subjects who do not suffer from any diseases, hemostatic defects, kidney or liver diseases and didn't receive any medical treatment at least 2 weeks before obtaining the samples.

Methods:

All subjects were subjected to the following:

\section{1-History taking and clinical examination.}

2- Laboratory investigations :

- Complete blood count (CBC) using sysmexkx 21 Roche diagnostic

-Urea using Diamon diagnostic reagents based on Berthelot enzymatic colorimetric method. ${ }^{[6]}$

- Serum creatinine using Spectrum Diagnostic reagents based on buffered kinetic Jaffé reaction without deproteinization. ${ }^{[7]}$
- Serum iron and TIBC using Spectrum Diagnostic reagents. ${ }^{[8]}$

- Serum ferritin using Vidas-Biomerieux based on enzyme linked fluorescent assay (ELFA) technique. The assay principle combines a one step enzyme immunoassay sandwich method with a final fluorescent detection. ${ }^{\text {[9] }}$

- Serum erythropoietin by ELISA using DRG* EPO ( Erythropoietin) (EIA3646) kits. ${ }^{[10]}$

-Serum hepcidin measurements by ELISA technique using Cusabio reagents from Cusabio Biotech Co., LTD (USA). The assay employs quantitative sandwich immunoassay technique. ${ }^{[11]}$

\section{Blood Sampling:}

$9 \mathrm{mls}$ venous blood were obtained by venipuncture divided into:

*2 mls blood on $\mathrm{K}_{2}$ EDTA, the concentration of $\mathrm{K}_{2}$ EDTA is $1.5 \pm 0.25 \mathrm{mg} / \mathrm{ml}$ blood for complete blood count (CBC).

*2 mls blood in a plain tube without anticoagulant for hepcidin assay. Samples are allowed to clot for 2 hours at room temperature before centrifugation for 15 minutes at $1000{ }^{x} \mathrm{~g}$ . Separated serum was aliquoted and stored at $20{ }^{\circ} \mathrm{C}$.

$* 2$ mls blood in a plain tube without anticoagulant between 7.30 am and12 noon for erythropoietin assay. Samples are allowed to clot between $2^{\circ} \mathrm{C}$ and $8^{\circ} \mathrm{C}$ for 2 hours before centrifugation in refrigerated centrifugation for 15 minutes at $1000^{\mathrm{x}} \mathrm{g}$. Separated serum was aliquot and stored at $-20{ }^{\circ} \mathrm{C}$.

$* 3 \mathrm{mls}$ blood in a plain plastic tube without anticoagulant. Samples are allowed to clot for half an hour at $37^{\circ} \mathrm{C}$ before centrifugation for 15 minutes at $1000{ }^{\mathrm{x}} \mathrm{g}$ for measurement serum urea, creatinine, serum iron, TIBC and serum ferritin.

-Statistical analysis: The collected data was tabulated and analyzed using SPSS software version 14 (SPSS Inc, Chicago, ILL Company). Data were expressed as mean \pm $\mathrm{SD}$, standard deviation, ANOVA, least significant difference (LSD) and Pearson correlation studies.

\section{RESULTS}

Our study included 50 patients 27 (54\%) $O$ in group I, 23 (46\%) $\rho$ in group II and 20 
subjects as control group (group III), their age ranges from (27-67years) selected from hemodialysis unit of Benha teaching hospital. Patients suffers from end stage renal disease (ESRD) and on regular hemodialysis 3 sessions per week and they have taken erythropoiesis stimulating agent therapy regularly.

The statistical analysis of laboratory results of $\hat{\partial}, q$ groups and control group showed the following:

Serum hepcidin was high in both patients groups but higher in group with (mean \pm SD) $(344 \pm 149.2)$ than $\delta$ group $(387 \pm 112.02)$ versus $(139.7 \pm 43.6)$ for the control group and with statistical significance difference between groups $(\mathrm{P}<0.01)$.

Hemoglobin was lower in both $\hat{O}$,,+ groups compared to control (mean $\pm \mathrm{SD}$ ), $(9.3 \pm 1.5),(8.8 \pm 1.4)$ versus $(13.9 \pm 1.2)$ and with statistical significance $(\mathrm{P}<0.01)$.

Serum ferritin level was also elevated in patients than control group and more higher in $\widehat{\delta}$ than 9 patients with (mean \pm SD), (254.9 \pm 89.8$),(187.9 \pm 66.5), \quad$ versus $(87.3 \pm 13.02)$ and also with statistical significance $(\mathrm{P}<0.01)$ also age, urea, creatinine were higher in patients groups with statistical significance $(\mathrm{P}<0.01)$, but serum erythropoietin was lower in patients groups than control and also, serum iron, TIBC capacity and with statistical significance $(\mathrm{P}<0.01)$. Table (1), figure (1)

The least significant difference (LSD) between male and female groups in different laboratory parameters showed: Significant difference in serum ferritin $(\mathrm{P}<0.01)$ and serum iron $(\mathrm{P}<0.05)$, but serum urea, creatinine, hemoglobin, TIBC, erythropoietin, hepcidin were insignificantly different between males and females groups ( $\mathrm{P}>0.05)$. Table (2)

Significant negative correlation between hepcidin and serum hemoglobin, iron, total iron binding capacity and erythropoietin $(\mathrm{P}<0.01)$ in the females group and in the male group $(\mathrm{P}<0.05)$. (figure 2,3$)$

NO significant correlation between hepcidin and serum urea and creatinine in both $\hat{O}, q$ groups. Moreover, serum hepcidin and serum ferritin had positive significant correlations $(\mathrm{P}<0.01)$ in $\widehat{\sigma}$ group and in $q$ group $(\mathrm{P}<0.05)$. Table (3), figure (4).

Table (1): Simple analysis of variance (ANOVA) for group I (males group), group II (females group) and group III (control group)

\begin{tabular}{llllll}
\hline & $\begin{array}{l}\text { Group I } \\
\text { mean } \pm \text { SD }\end{array}$ & $\begin{array}{l}\text { Group II } \\
\text { mean } \pm \text { SD }\end{array}$ & $\begin{array}{l}\text { Group III } \\
\text { mean } \pm \text { SD }\end{array}$ & F & P \\
\hline Urea $\mathrm{mg} / \mathrm{dl}$ & $85.04 \pm 23.5$ & $82.0 \pm 21.7$ & $26.3 \pm 4.5$ & 62.7 & $<0.01^{* *}$ \\
\hline Creatinine $\mathrm{mg} / \mathrm{dl}$ & $5.3 \pm 1.6$ & $5.08 \pm 1.29$ & $0.79 \pm 0.17$ & 89.4 & $<0.01^{* *}$ \\
\hline Haemglobin $\mathrm{g} / \mathrm{dl}$ & $9.3 \pm 1.5$ & $8.8 \pm 1.4$ & $13.9 \pm 1.2$ & 93.68 & $<0.01^{* *}$ \\
\hline Iron $\mathrm{ug} / \mathrm{dl}$ & $68.1 \pm 14.9$ & $57.6 \pm 17.8$ & $88.7 \pm 22.3$ & 16.1 & $<0.01^{* *}$ \\
\hline TIBC \% & $222 \pm 49.9$ & $201 \pm 40.2$ & $307.3 \pm 53.8$ & 29.48 & $<0.01^{* *}$ \\
\hline Ferritin $\mathrm{ng} / \mathrm{ml}$ & $254.9 \pm 89.8$ & $187.9 \pm 66.5$ & $87.3 \pm 13.02$ & 34.6 & $<0.01^{* *}$ \\
\hline Erythropoietin $\mathrm{mIu} / \mathrm{ml}$ & $10.6 \pm 4.3$ & $7.9 \pm 4.0$ & $23.9 \pm 8.8$ & 45.3 & $<0.01^{* *}$ \\
\hline Hepcidin $\mathrm{ng} / \mathrm{ml}$ & $344 \pm 149.2$ & $387 \pm 112.02$ & $139.7 \pm 43.6$ & 28.9 & $<0.01^{* *}$ \\
\hline Age Years & $50.2 \pm 10.2$ & $48.8 \pm 8.4$ & $45.1 \pm 8.9$ & 1.77 & $>0.05^{\wedge}$ \\
\hline
\end{tabular}

mean, standard deviation (SD), $\mathrm{F}$ and $\mathrm{P}$ value.

$P>0.05$ (Non Significant $)=\wedge$

$P<0.05$ (Significant) $=*$

$P<0.01$ (Highly Significant) $=* *$

Group I : Male patients with chronic renal failure .

Group II : Female patients with chronic renal failure.

Group III: Control group. 

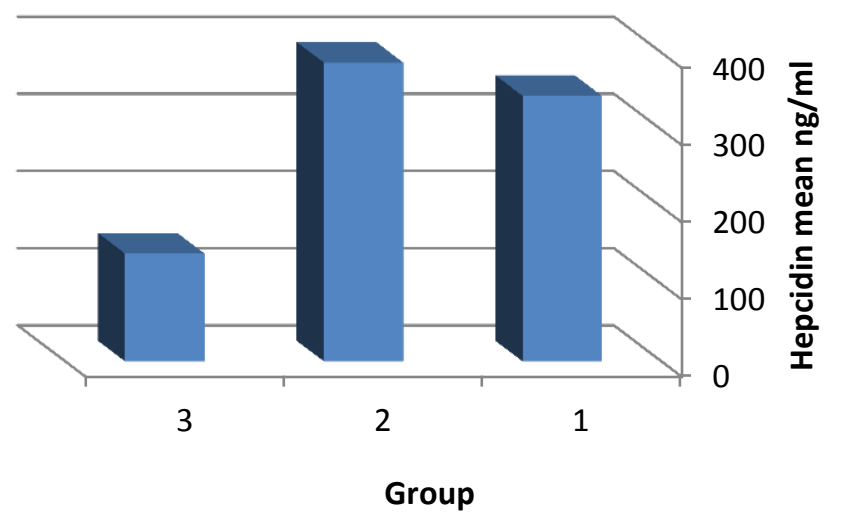

Figure (1): Comparison of hepcidin mean in the different studied groups:

Table (2): Least significance difference (LSD) of the different parameters measured in the different study groups

\begin{tabular}{lllllll}
\hline & GI and GII & \multicolumn{2}{l}{ GII and GIII } & \multicolumn{2}{l}{ GI and GIII } \\
& LSD & P & LSD & $\mathrm{P}$ & LSD & $\mathrm{P}$ \\
\hline Urea & 3.04 & $>0.05^{\wedge}$ & 55.7 & $<0.01^{* *}$ & 58.7 & $<0.01^{* *}$ \\
$m g / d l$ & & & & & & \\
\hline Creatinine $m g / d l$ & 0.24 & $>0.05^{\wedge}$ & 4.28 & $<0.01^{* *}$ & 4.53 & $<0.01^{* *}$ \\
\hline Haemglobing/dl & 0.456 & $>0.05^{\wedge}$ & 5.04 & $<0.01^{* *}$ & 4.59 & $<0.01^{* *}$ \\
\hline Iron $u g / d l$ & 10.4 & $<0.05^{*}$ & 31.02 & $<0.01^{* *}$ & 20.58 & $<0.01^{* *}$ \\
\hline TIBC\% & 20.44 & $>0.05^{\wedge}$ & 105.7 & $<0.01^{* *}$ & 85.2 & $<0.01^{* *}$ \\
\hline Ferritin $n g / m l$ & 66.9 & $<0.01^{* *}$ & 100.6 & $<0.01^{* *}$ & 167.6 & $<0.01^{* *}$ \\
\hline Erythropiotin $\mathrm{mIu} / \mathrm{ml}$ & 2.72 & $>0.05^{\wedge}$ & 15.9 & $<0.01^{* *}$ & 13.26 & $<0.01^{* *}$ \\
\hline Hepcidin $n g / m l$ & 43.2 & $>0.05^{\wedge}$ & 247.6 & $<0.01^{* *}$ & 204.4 & $<0.01^{* *}$ \\
\hline P & & & & &
\end{tabular}

$P>0.05$ (Non Significant $){ }^{\wedge}$

$P<0.05$ (Significant) $=*$

$P<0.01$ (Highly Significant) $=* *$

Group I : Male patients with chronic renal failure .

Group II : Female patients with chronic renal failure.

GroupIII: Control group.

Table (3): Pearson correlations between hepcidin and the different parameters (urea, creatinine, haemoglobin, iron, TIBC, Ferritin and Erythropoietin) in the different studied groups.

\begin{tabular}{|c|c|c|c|c|c|c|}
\hline & \multicolumn{6}{|c|}{ Hepcidin (ng/ml) } \\
\hline & \multicolumn{2}{|c|}{ GroupI } & \multicolumn{2}{|c|}{ GroupII } & \multicolumn{2}{|c|}{ GroupIII } \\
\hline & $\mathrm{r}$ & P & $\mathrm{r}$ & $\mathrm{P}$ & $\mathrm{r}$ & $\mathrm{P}$ \\
\hline Urea $m g / d l$ & -0.009 & $>0.05^{\wedge}$ & 0.192 & $>0.05^{\wedge}$ & -0.172 & $>0.05^{\wedge}$ \\
\hline Creatinine $m g / d l$ & -0.077 & $>0.05^{\wedge}$ & 0.103 & $>0.05^{\wedge}$ & 0.094 & $>0.05^{\wedge}$ \\
\hline Haemglobin $g / d l$ & -0.481 & $<0.05^{*}$ & -0.730 & $<0.01 * *$ & -0.299 & $>0.05^{\wedge}$ \\
\hline Iron $u g / d l$ & -0.464 & $<0.05^{*}$ & -0.826 & $<0.01 * *$ & 0.137 & $>0.05^{\wedge}$ \\
\hline TIBC \% & -0.469 & $<0.05^{*}$ & -0.776 & $<0.01 * *$ & 0.235 & $>0.05^{\wedge}$ \\
\hline Ferritin $n g / m l$ & 0.83 & $<0.01 * *$ & 0.5 & $<0.05^{*}$ & 0.203 & $>0.05^{\wedge}$ \\
\hline Erythropoietin $\mathrm{mIu} / \mathrm{ml}$ & -0.489 & $<0.05^{*}$ & -0.863 & $<0.01 * *$ & 0.266 & $>0.05^{\wedge}$ \\
\hline \multicolumn{7}{|c|}{$\begin{array}{l}P>0.05 \text { (Non Significant) }=\wedge \\
P<0.05 \text { (Significant) }=* \\
P<0.01 \text { (Highly Significant) }=* * \\
\text { Group I : Male patients with chronic renal failure. } \\
\text { Group II : Female patients with chronic renal failure. } \\
\text { GroupIII: Control group. }\end{array}$} \\
\hline Hoda E. Ahmed \& Amal E. El-Maghrab & & WWW. & d.zu.e & & & -289 \\
\hline
\end{tabular}




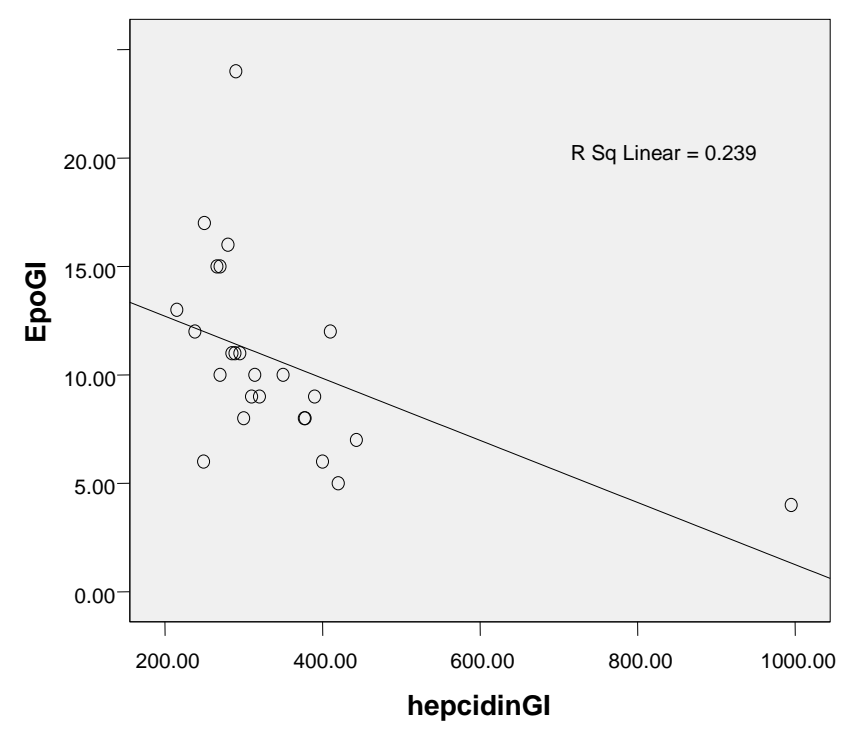

Figure (2): Correlation between hepcidin and erythropoietin in group I

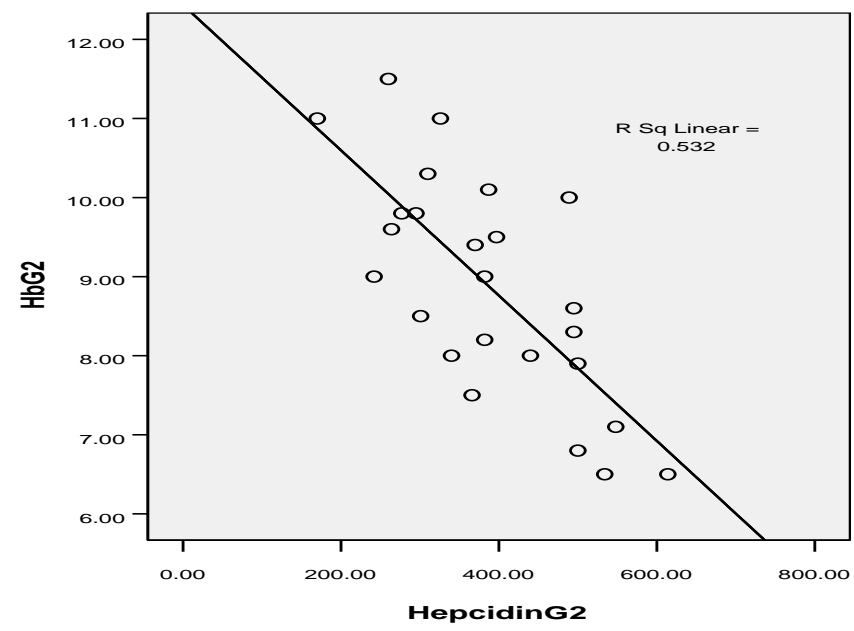

Figure (3): Correlation between hepcidin and Haemoglobin in groupI I

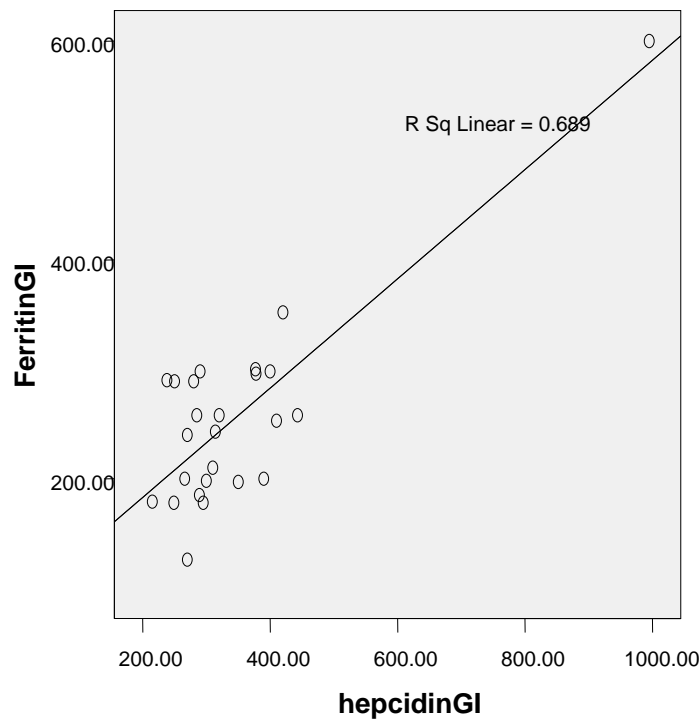

Figure (4):Correlation between hepcidin and ferritin in group I 


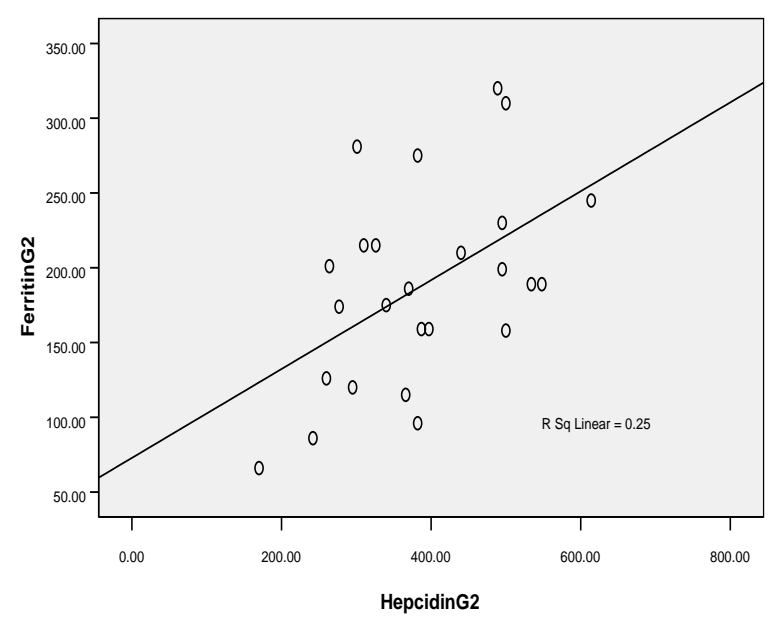

Figure (5): Correlation between hepcidin and ferritin in group II

\section{DISCUSSION}

Hepcidin is involved in iron restrict erythropoiesis associated iron deficiency anemia and anemia of chronic disorders in chronic renal failure. Hepcidin-25 regulates iron homeostasis binding the iron transporter ferroportin causing its degradation. Moreover it decreases release of iron from intracellular stores and its intestinal absorption. ${ }^{[12],[13]}$

Hepcidin may play a significant role in the pathogenesis of chronic kidney disease (CKD) complications associated with disturbed iron metabolism. Patients with hyperferritinemia have impaired hepcidin expression. As in hemochromatosis it is associated with an attenuation of atherosclerosis, thus hepcidin might accelerate atherosclerosis by preventing iron exit from macrophage and other cells in the arterial wall. ${ }^{[14]}$

Prohepcidin is the precursor of hepcidin, iron overload and inflammation increase hepcidin expression, whereas anemia and hypoxia suppress it. In a study done by (El Ftheriads et al., 2006) showed that prohepcidin level may be associated with the factors that inhibit erythropoiesis in hemodialysis patient. [15],[16]

In a cross sectional study on 505 non dialysis CKD patient, not treated with parenteral iron. Hepcidin level was significantly increased according to CKD stage without any association with estimated GFR, in contrary hepcidin level was found to be negatively associated with hemoglobin concentration in high ferritin group. ${ }^{[17]}$

In our study, serum hepcidin was higher in both $\hat{O}$,, groups of patients of end stage renal disease ESRD on regular hemodialysis in comparison to control group with statistical significance $(\mathrm{P}<0.01)$ and its concentration was higher in $q$ group. table (1),(2), figure (1)

This is matched on study done on 103 CKD patients versus 100 healthy individuals. Hepcidin-25 concentrations was significantly increased compared to healthy subjects. ${ }^{[12]}$, also a study on patients with combined heart, renal failure and anemia, hepcidin levels was increased in comparison to healthy reference populations. ${ }^{[18],[19],[20]}$

In this study hepcidin was negatively correlated to serum hemoglobin, serum iron and total iron binding capacity $(\mathrm{P}<0.01)$. (Table 3), figure (3).

Which is matched with on a study on Japanese dialysis patients with erythropoietin (Epo resistant anemia), multiple factors are included such as iron deficiency and inflammation and 
increased interleukin-6, high sensitive CRP may contribute to this condition. ${ }^{[21]}$

Ferritin is considered a significant predictor of hepcidin levels in absence of apparent inflammation and hepcidin also correlated with ferritin in patients on hemodialysis and is considered a marker of inflammation as highly sensitive CRP. ${ }^{[5]}$

In comparison to our study serum ferritin was elevated in patients than control group and was found to be more in $\hat{\sigma}$ than $q$ of studied group and the correlation with control group was significant $(\mathrm{P}<0.01)$ and was positively significant correlated with hepcidin $(\mathrm{P}<0.05)$. Table (1), (2), (3), figure (4), (5).This is concomitant with a study done by (Costo et al., 2008) on 50 patients on hemodialysis versus 25 control, prohepcidin level, serum ferritin and also CRP, IL6 were higher especially in non responder group to Epo therapy than control and demonstrated that prohepcidin, may be a good marker of resistance of epo therapy in heamodialysis patients. ${ }^{[22]}$

Also (Zaritky et al., 2009) found association between hepcidin and soluble transferrin receptor and suggested hepcidin as biomarker of iron status and erythropoietin resistance. ${ }^{[23]}$

Recombinant human erythropoietin had been used in chronic renal failure patients which improve outcome of patient on regular chronic hemodialysis, but failure of response to epoetin therapy was recorded. Epo resistance is used to describe patients in whom the target hemoglobin not achieved despite a greater than usual dose of erythropoietinstimulating agent about $35 \%$ to $65 \%$ of hemodialysis patients show signs of inflammation suppress of bone marrow erythropoiesis secondary to release of cytokines in addition to protein energy malnutrition and wasting, low serum albumin. ${ }^{[24],[25]}$

Oxidative stress may contribute to the hypo responsiveness to epotein therapy directly through promoting lipid peroxidation in cell membranes which leads to erythrocyte fragility and reduce life span. ${ }^{[26]}$

Moreover, severe hyperparathyroidism and aluminum overload decrease response to erythroid progenitor cells, also nutritional disorders such as vitamin $\mathrm{B}_{12}$, folic acid and vitamin $\mathrm{C}$ deficiency. ${ }^{[27]}$

Also the resistance to erythropoietin therapy in hemodialysis patients may be associated with higher adiponectin levels and inflammatory process altered iron metabolism leads to functional iron deficiency in lean patients in comparison with overweight, obese patients. ${ }^{[28]}$

In this study erythropoietin was lower in patient groups than control with statistically significance $\quad(\mathrm{P}<0.01)$ while there was insignificant correlation between male and female groups of patients, but there was negative correlation with serum hepcidin with statistic significance $(\mathrm{P}<0.01)$.table $\quad(1)$, (2), (3), figure (2). This is matched by a study on CKD patients on hemodialysis and hyporesponsive to erythropoietin therapy serum hemoglobin was lower and both serum ferritin and hepcidin concentration were high which reflects subclinical inflammation. ${ }^{\text {29],[30],[31] }}$

(Rabab et al., 2015) also demonstrated significant correlation between patients on maintenance hemodialysis and epotherapy with serum hepcidin, hemoglobin, total iron binding capacity, serum iron especially non Epo responder in comparison to control and also suggest a role of hepcidin in Epo resistance group. ${ }^{[30]}$ While (Weiss et al., 2009) demonstrated that using high or low flux bio compatible dialyser may affect hepcidin concentration and recommend Epo therapy not iron therapy reduces hepcidin. ${ }^{[23]}$

\section{CONCLUSION}

Serum hepcidin level contributes to severity of anemia and resistance of erythropoiesis stimulating agent on CKD patients on regular hemodialysis, although recombinant human erythropoietin has been used to correct anemia of chronic renal disease but few 
number of patients fail to respond. So hepcidin can be used as a marker of iron status and erythropoietin resistance.

Iron status should be checked regularly to those patients and correction with parenteral iron is recommended, also infection, inflammatory conditions and nutritional status should be evaluated and treated and also regular adherence to erythropoietin therapy in proper dose.

\section{REFERENCES}

1) Ganz $T$, Nemeth E. Iron balance and the role of hepcidin in chronic kidney disease. Semin Nephrol.2016 Mar; 36(2):87-93.

2) Tsuchijo K, Nitta K. Hepcidin is a potential regulator of iron status in chronic kidney disease. Ther Apher Dial. 2013 Feb; 17(1):1-8.

3) Atlkinson MA, White CT. Hepcidinin anemia of chronickidney disease: review for the pediatric nephrologist. Pediatr Nephrol. 2012 Jan; 27(1):33-40.

4) Jaueguj M, Choukroun G. Factors affecting the response to erythropoiesis-stimulating agents. Nephrol Ther.2006 Sep; 2 Suppl 4: S274-82.

5) Sany D, Elsawy AE, El Shahawy Y. Hepcidin and regulation of iron homeostasis in maintenance hemodialysis patients. Saudi J Kidney Dis Transpl.2014 Sep; 25(5):96773.

6) Tabacco A et al.,(1979): Clin. Chem., 25: 336-337.

7) Bower LD and Wong ET (1980):Kinetic serum creatinine assays. Acritical evaluation and review. Clin. Chem., 26: 555.

8) Fairbank VF and Klee GG(1987): Biochemical aspect of hematology in Tietz NW. ed. Fundamentals of clinical chemistry .3rd ed., Philadelphia :WB Saunders :789824.

9) Challand GS, Mickaeldoudis A, Watfa RR, Coles SJ and Macklin JL (1980): Distribution of hemoglobin in patients presented to their general practitioner and its correlation with serum ferritin. Ann. Clin. Biochem.27, 15-20.

10) Goldberg MA., Dunning SP. and Bunn HF. (1988): Regulation of erythropiotin gene: Evidence that the oxygen sensor is a heme protein. Science, 242:1412-1415.

11) Ganz T., Olbina G., Girelli D., Nemeth E. etWesterman M (2008): Immunoassay for human serum hepcidin. Blood, 112, 42924297.
12) Troutt JS, Butterfield AM, Konrad RJ. Hepcidin-25 concentrations are markedly increased in patients with chronic kidney disease and are inversely correlated with estimated glomerular filtration rate. J Clin Lab Anal. 2013 Nov; 27(6):504-10.

13) Takasawa $K$, Takaeda $C$, Maeda $T$, Ueda $N$. Hepcidin-25, mean corpuscular volume, and ferritin as predictors of response to oral iron supplementation in hemodialysis patients. Nutrients. 2014 Dec; 29,7(1):13-18.

14) Nakanishi T, Hasuike $Y$, Otaki $Y$, Kida $A$, Nonoguchi H, Kuragano T.Hepcidin: another culprit for complications in patients with chronic kidney disease. Nephrol Dial Transplant. 2011 Oct; 26(10):3092-100.

15) Elefheriadis T, Kartsios $C$, Liakopoulos V, Antoniadi G, Ditsa M, Papadopoulos C, et al., Does hipcidin affect erythropoiesis in hemodialysis patients? Acta Haematol. 2006; 116(4):238-44.

16) Malyszko J, Malyszko JS, Hryszko T, Pawlak K, Mysliwiec M. Is hepcidin a link between anemia, inflammation and liver function in hemodialyzed patients? Am J Nephrol. 2005 Nov-Dec; 25(6):586-90.

17) Uehato $T$, Tomosugi $N$, Shoji $T$, Sakaguche Y, Suzuki A, Kaneko T, et al., Serum hepcidin-25 levels and anemia in non-dialysis chronic kidney disease patients: a cross sectional study. Nephrol Dial Transplant. 2012 Mar; 27(3):1076-83.

18) Van der putten K, Jie KE, Van den Broek D, Braem B, Guillard CA. Hepcidin-25 is a marker of response rather than resistance to exogenous erythropoietin in chronic kidney disease/ chronic heart failure patients. Eur J Heart Fail.2010 Sep; 12(9):943-50.

19) Kato A. Increased hepcidin-25 and erythropoietin responsiveness in patients with cardio-renal anemia syndrome. Futrure Cardiol. 2010 Nov; 6(6):769-71.

20) Aydin $Z$, Gursu M, Karadag S, Vzun $S$, Sumno A, DoventosY,et al. The relationship of prohepcidin levels with anemia and inflammatory markers in non-diabetic uremia patients. A controlled study. Ren Fail. 2014 Sep; 636(8):1253-7.

21) Shinzato $K$, Abo K, Furusu A, Harada K, Shinzato K, Miyazaki M, et al.Serumprohepcidin level and iron homeostasis in Japanese dialysis patients with erytropoitin (EPO. Resistant anemia. Med Sci Monit. 2008 Sep;14(9):CR431-7.

22) Costa $E$, Pereira BJ, Roche-Pereira $P$, Rocha S, Reis F, Castro E, et al. Role of 
prohepcidin, inflammatory markers and iron status in resistance o rhEpo Therapy in hemodialysis patients. Am J Nephrol, 2008; 28(4):677-83.

23) Zaritsky J, Young B, Wang HJ, Westerman M, Olbina G, Nemeh E, et al. Hepcidin- a potential novel biomarker for iron status in chronic kidney disease. Clin J Am Soc Nephrol.2009 Jun; 4(6):1051-6.

24) Barsan L, Stanciu A, Stancu S, Locatelli F. Inflammation and resistance to treatment with recombinant human erythropoiin. J RenNutr. 2005 Jan; 15(1):137-41.

25) Kwack C, Balakrishman VS. Managing erythropoietin hyporesponsiveness. Semin Dial Mar-Apr:19(2):146-51.

26) Do Sameiro-faria $M$, Ribeiro $S$, RochaPereira P, Fernandes J, Reis F, Bronze-da Rocha E, et al. Body mass index and resistance to recombinant human erythropoietin therapy in maintenance hemodialysis patients. Ren Fail.2013; 35(10):1392-8.

27) Maly S, Zko J, Malyszko JS, Mysliwiec M. Hyporesponsiveness o erythropoietin therapy in hemodialyzed patients: Potential role of prohepcidin, hepcidin, and inflammation. Ren Fail.2009; 31(7):544-8.

28) $X u$ Y, Ding $X Q$, Zou JZ, Liu ZH, Jiang SH, Chen YM. Serum hepcidin in hemodialysis patients. Association with iron status and micro-inflammation. J In Med Res.2011; 39(5):1961-7.

29) Arabul M, Gullulu M, Yilmaz Y, Eren MA, Baran B, Gul CB, etal. Influence of erythropoietin therapy on serum prohepcidin levels in dialysis patients. Med Sc iMoni. 2009 Nov:15(11):CR583-7.

30) Rabab Z, Amin $H$, Abbas $K$, Hussain $S$, Ullah MI, Mohsin S.Serum hepcidin levels in patients with end-stage renal disease on hemodialysis. Saudi J Kidney Dis ranspl. 2015 Jan; 26(1):19-25.

31) Weiss G, Theurl I, Eder S, Koppelstaetter C, Kurz K, Sonnweber T, et al. Serum hepcidin concentration in chronic heamodialysis patients: associations and effects of dialysis, iron erythropoietin therapy. Eur J Clin Inves. 2009 Oct; 39(10):883-90. 